\title{
Nitrogen deposition and its impact on forest ecosystems in the Czech Republic - change in soil chemistry and ground vegetation
}

\author{
Radek Novotný (1), Václav \\ Buriánek ${ }^{(1)}$, Vít Šrámek ${ }^{(1)}$, \\ Iva Hůnová(2), Irena Skořepová (3), \\ Miloš Zapletal ${ }^{(4-5)}$, Bohumír \\ Lomský (1)
}

\begin{abstract}
A repeated soil survey (1995 and 2006) on 66 ICP Forests pair plots in the Czech Republic revealed a significant relationship between modeled nitrogen deposition and nitrogen concentration in the soil. Nitrogen deposition was modeled for the years 1995, 2004 and 2006. We found a more significant relationship between deposition data in 2004 and soil data in 2006 than between deposition and soil data from the same year 2006. Concentration of total nitrogen in forest soil increased from 1995 to 2006. Forest soil showed effects of increased nitrogen input from the humus layer to around $20 \mathrm{~cm}$ depth of mineral soil. The occurrence and cover of nitrophilous species in the herb layer increased from 1995 to 2006 in 25\% of the analyzed plots, which corresponds to the nitrogen increase in forest soil. The results suggest that nitrogen deposition still represents a threat for Czech forest ecosystems.
\end{abstract}

Keywords: Nitrogen Deposition, Soil Chemistry, Ground Vegetation, Ecosystem Changes, Norway Spruce

2006, Podrázský \& Remeš 2007). After desulphurisation of pollution sources during the 90s, ambient air quality improved rapidly, though forest ecosystems did not respond in the same way. Acid deposition led to base cations leaching from upper soil horizons and then to crown transparency (Materna 1986, Rothe et al. 2002, Lomský \& Šrámek 2004). Soil acidification by sulphur and $\mathrm{N}$ compounds can cause both a loss of base cations and mobilization of aluminium and other metal compounds, and it has many consequences on forest vitality and vulnerability to other stress factors (De Vries et al. 2000, Schaaf et al. 2004). In recent decades, more attention has been paid to $\mathrm{N}$ and its compounds.

$\square$ (1) Forestry and Game Management Research Institute, Strnady 136, 25202 Jíloviště (Czech Republic); (2) Czech Hydrometeorological Institute, Na Šabatce 2050/17, 14306 Prague (Czech Republic); (3) Czech Geological Survey, Geologická 6, 15200 Prague (Czech Republic); (4) Ekotoxa - Centre for Environment and Land Assessment, Otická 37, 74601 Opava (Czech Republic); (5) Silesian University in Opava, Faculty of Philosophy and Science, Masarykova 37, 74601 Opava (Czech Republic)

@ Radek Novotný (novotny@vulhm.cz)

Received: Sep 01, 2015 - Accepted: Mar 11, 2016

Citation: Novotný R, Buriánek V, Šrámek V, Hůnová I, Skořepová I, Zapletal M, Lomský B (2016). Nitrogen deposition and its impact on forest ecosystems in the Czech Republic change in soil chemistry and ground vegetation. iForest 10: 48-54. - doi: 10.3832/ifor1847009 [online 2016-06-29]

Communicated by: Elena Paoletti

De Vries et al. (2014) reported a $25 \%$ decrease of $\mathrm{N}$ emissions since 1985 , but the amount of $\mathrm{N}$ emission is still roughly four times as high as in pre-industrial times. Eutrophication continues to be a serious threat to European ecosystems. In 1980 critical loads of nutrient $\mathrm{N}$ were exceeded in about $67 \%$ of the European area, and are expected to decrease to $42 \%$ in 2020 (Posch et al. 2012). Between 1980 and 2020, ecosystems of Central Europe were confirmed to be at high risk of eutrophication (Posch et al. 2012). Critical loads of nutrient $\mathrm{N}$ were exceeded in about $100 \%$ of the forested area of the Czech Republic in 1994 (Zapletal 2006), and in 95\% of the forested area in 2007 (Zapletal 2014).

The effect of $\mathrm{N}$ input on the forest ecosystem is complex and disputable - from fertilisation (Solberg et al. 2004, 2009, Jandl et al. 2012) to acidification (Zapletal 1998, 2001, 2006, Augustin et al. 2005, Vícha et al. 2012). Also its potential to cause a loss of diversity in understory vegetation in forest stands is complex (Okland 1995, Wamelink et al. 2008, Kreutzer et al. 2009, Buriánek et al. 2013). The relationship between $\mathrm{N}$ addition and biodiversity has been experimentally tested (Reich et al. 2001), showing that $\mathrm{N}$-addition leads to a decrease in biodiversity. Further negative influences of $\mathrm{N}$ deposition may be the reduction of root biomass, mycorrhiza and microbial activity, and this in turn may negatively affect nutrient uptake, especially uptake of phosphorus, leading to nutrient imbalance in foliage (Salih \& Andersson 
Tab. 1 - Basic characteristics of the plots assessed in both soil surveys (1995 and 2006) and chosen for comparison. The total number of plots was 66 .

\begin{tabular}{llr}
\hline Parameter & Tree species / & Number \\
& range of parameter & 46 \\
\hline Main tree species & Norway spruce & 7 \\
& Scots pine & 3 \\
& European beech & 10 \\
clear cut between surveys & 0 \\
& $<50$ & 45 \\
Age in 1995 & $51-100$ & 8 \\
& $>100$ & 13 \\
\hline nge in 2006 & $<50$ & 8 \\
& $51-100$ & 28 \\
Altitude & $>100$ & 25 \\
& not known & 5 \\
\hline & $<400$ m a. s. l. & 8 \\
& $401-800$ m a. s. l. & 49 \\
\hline
\end{tabular}

1999, Schulze et al. 2005, Mellert et al. 2008, Fujita et al. 2010). In connection with higher $\mathrm{N}$ input to the forest stands, a positive fertilization effect on growth is likely. For instance, Austrian forest soil is still deficient in $\mathrm{N}$ and stands respond positively to higher $\mathrm{N}$ deposition (Jandl et al. 2012). The positive effect of $\mathrm{N}$ on forest growth is mentioned by, among others, Solberg et al. (2004, 2009). On the other hand, previous studies confirmed that forest ecosystems turned from $\mathrm{N}$-limited to $\mathrm{N}$-saturated (Mellert et al. 2005, Corre et al. 2007, Kreutzer et al. 2009) and that negative effect of elevated $\mathrm{N}$ input causes nutrient imbalance in forest foliage (Braun et al. 2010, Lomský et al. 2011, Lomský et al. 2012).

The aim of our paper was to evaluate changes in soil chemistry and in ground level vegetation composition caused by $\mathrm{N}$ deposition between two forest surveys which were done in the Czech Republic.

\section{Material and methods}

\section{Ground vegetation assessment}

Forest vegetation was monitored within the ICP Forests Programme in accordance with Canullo et al. (2011) at 154 selected plots in the Czech Republic. The assessment was repeated approximately every five years since 1995, taking about three years to assess all the 154 plots. At least three assessments were available for each plot. Basic investigation was carried out during the peak growing season, preferably during the summer, though in certain areas with significant seasonality (e.g., in floodplain forests) spring, or late summer to autumn, were also chosen for survey. The status of the vegetation was evaluated using classic semi-quantitative phytosociological relevés. The assessment was carried out at the center of circular plots with an area of $400 \mathrm{~m}^{2}$ (radius of $11.28 \mathrm{~m}$ ). A modified semi-quantitative seven-item combi-

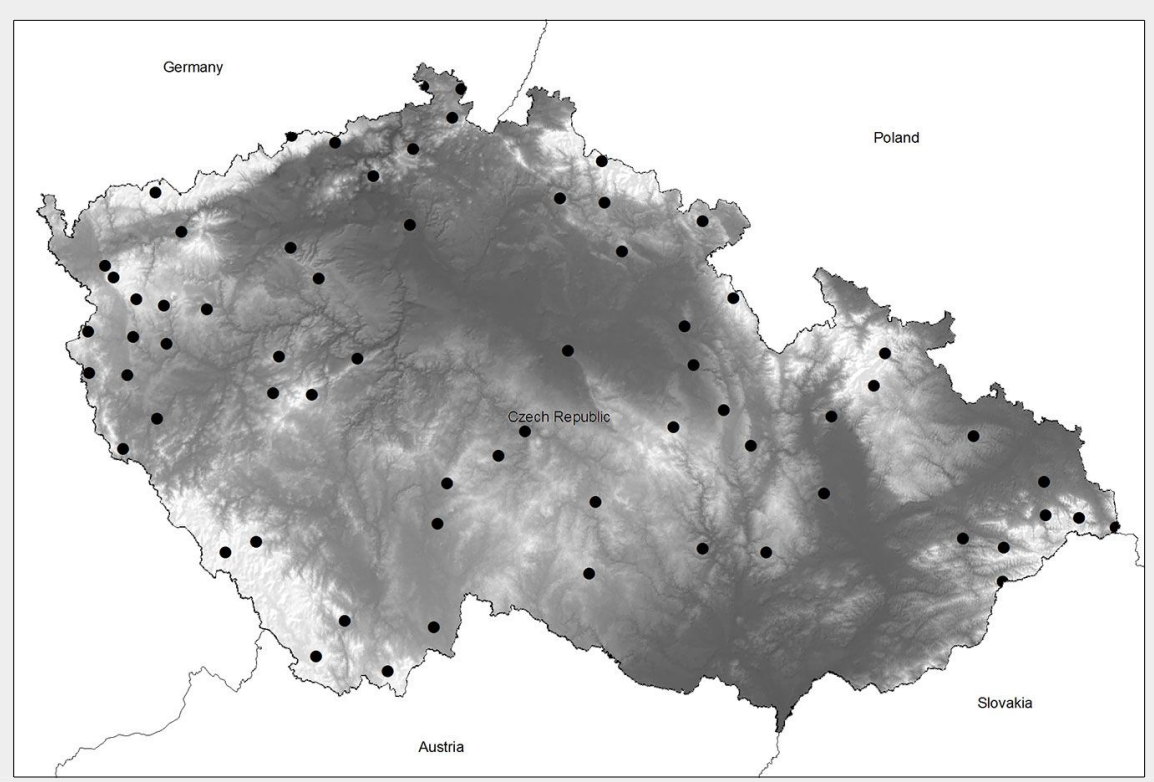

Fig. 1 - Location of the plots (black dots) selected for the vegetation survey in the Czech Republic. ned scale of abundance and dominance was used, in accordance with the BraunBlanquet's concept (Braun-Blanquet 1965), as described in Buriánek et al. (2013). Within ground level vegetation, we focused on species that are considered as indicators of increased $\mathrm{N}$ content in the soil and, at the same time, also occur at multiple sites (for example, Urtica dioica L., Geranium robertianum L., Impatiens parvifloral DC., Alliaria petiolata (M.Bieb.) Cavara \& Grande).

\section{Soil survey and data}

The first survey was done in 1995-1996 within a national inventory by using a national methodology for sampling (Fabiánek 2004); the second survey was carried out in 2005-2008 within the BioSoil project by using an international methodology (UNECE 2006). The main difference between the two surveys was the range of sampling. Soil samples were taken from soil pit at fixed depth every $10 \mathrm{~cm}(0-10 \mathrm{~cm}, 10-20$ $\mathrm{cm}, 20-30 \mathrm{~cm}$, etc.) up to $80 \mathrm{~cm}$ in the first survey and at fixed depths of $0-10 \mathrm{~cm}, 10-20$ $\mathrm{cm}, 20-40 \mathrm{~cm}$ and $40-80 \mathrm{~cm}$ in the second survey. We assessed selected soil parameters up to $20 \mathrm{~cm}$ depth, so that results were comparable as the sampling interval was the same down to $20 \mathrm{~cm}$ depth. We chose plots and parameters $\left(\mathrm{pH}\left(\mathrm{CaCl}_{2}\right)\right.$, $\mathrm{pH}\left(\mathrm{H}_{2} \mathrm{O}\right)$, total carbon and $\mathrm{N}$ concentration, $\mathrm{C} / \mathrm{N}$ ratio), and soil layers (humus layer, mineral soil $0-10 \mathrm{~cm}$ and mineral soil $10-20$ $\mathrm{cm}$ depth) which were analyzed in both surveys. The number of plot pairs was 66 . The main characteristics of the surveyed plots are summarized in Tab. 1.

Chemical analysis was carried out in accordance with the standard operating procedures which are recommended by the ICP Forests programme (UNECE 2006).

The distribution of plots across the Czech Republic is shown in Fig. 1 .

\section{Deposition data}

To estimate the atmospheric deposition of $\mathrm{N}$ and $\mathrm{H}^{+}$ions at selected plots, we used maps produced by adding wet and dry deposition flux maps with a fine spatial resolution of $1 \times 1 \mathrm{~km}$. The method was described in detail by Hůnová et al. (2011) and Hůnová et al. (2014). Wet deposition was calculated based on automated wet-only samples on a weekly basis, analyzed by standard methods with comprehensive QA/QC procedures. Dry deposition was estimated using the inferential method, combining measurements and modeling. A digital map of Czech forests produced from the European digital Land Use map (Corine Land Cover 2000 - http://etc-lusi.eionet.eu ropa.eu/CLC2000) was used. All maps were prepared using the software $\operatorname{ArcGIS}^{\oplus}$ Geostatistical Analyst (Johnston et al. 2001). For selected plots total $\mathrm{N}$ and total $\mathrm{H}^{+}$ions deposition in 1995, 2004 and 2006 were calculated.

\section{Data analyses}

After carrying out the exploratory data 
analysis, their departure from normal distribution was tested. Data sets were tested as dependent or independent samples (according to input data sets); non-parametric tests (Sign test, Wilcoxon pair test, Kruskal-Wallis ANOVA, Median test) were used, because normality was rejected after Shapiro-Wilk W-test. For testing the relationship between deposition and soil parameters, we also used non-parametric test (Spearman R and Kendall tau correlation). Statistical analysis of the data was performed using the package Statistica ${ }^{\circledR} \mathrm{Cz}$ version 12.0 (StatSoft Inc., Tulsa, OK, USA).

\section{Results}

\section{Vegetation assessment}

Overall, the selected nitrophilous indicator species were identified at 74 out of 154 plots (48\%) in 2011. At 39 of these sites, their occurrence was rather sporadic (1-2 species with coverage of up to $0.5 \%$ ). At 13 sites, the occurrence of nitrophilous species was evaluated as significant (usually more species, though with a relatively low coverage of up to $5 \%$ ). At 22 sites, there was a significant occurrence of nitrophilous species with a high coverage (above $5 \%)$. At other sites (80 plots) the occurrence of nitrophilous species was not recorded. At a total of 38 sites (25\%), the

Tab. 2 - Non-parametric test of difference in nitrogen concentration and $\mathrm{C} / \mathrm{N}$ ratio in soil between plots with and without selected nitrophilous species. P-values of Kruskal-Wallis ANOVA (KW) and median test (MT) are shown. (w): number of plots with nitrophilous species; (wo): number of plots without nitrophilous species; (FH): humus layer; (M01): mineral soil $(0-10 \mathrm{~cm})$; (M12): mineral soil $(10-20 \mathrm{~cm})$; (Ntot): total nitrogen concentration in soil; $(\mathrm{C} / \mathrm{N})$ : carbon to nitrogen ratio in the soil.

\begin{tabular}{lllcccccc}
\hline \multirow{2}{*}{ Species } & \multirow{2}{*}{ w/wo } & & \multicolumn{2}{c}{ FH } & \multicolumn{2}{c}{ M01 } & \multicolumn{2}{c}{ M12 } \\
\cline { 4 - 8 } & & Test & Ntot & C/N & Ntot & C/N & Ntot & C/N \\
\hline Geranium & $24 / 121$ & KW & 0.205 & 0.000 & 0.074 & 0.000 & 0.007 & 0.000 \\
robertianum & & MT & 0.192 & 0.000 & 0.168 & 0.000 & 0.023 & 0.000 \\
\hline Impatiens & \multirow{2}{*}{$30 / 115$} & KW & 0.622 & 0.006 & 0.571 & 0.001 & 0.238 & 0.001 \\
parviflora & & MT & 0.966 & 0.045 & 0.388 & 0.045 & 0.203 & 0.000 \\
\hline Sambucus & \multirow{2}{*}{$33 / 112$} & KW & 0.320 & 0.045 & 0.233 & 0.001 & 0.233 & 0.000 \\
nigra & & MT & 0.345 & 0.033 & 0.152 & 0.001 & 0.523 & 0.000 \\
Urtica & \multirow{2}{*}{$50 / 95$} & KW & 0.693 & 0.000 & 0.011 & 0.000 & 0.001 & 0.002 \\
dioica & & MT & 0.772 & 0.000 & 0.012 & 0.000 & 0.000 & 0.001 \\
\hline
\end{tabular}

presence of nitrophilous species increased during the period analyzed (1995-2011), while a reduction was recorded at seven plots. In addition to the above mentioned species, also Rubus spp., Galium aparine L., Lamium purpureum L. or Anthriscus sylvestris (L.) Hoffm. showed an increased occurrence. Regarding woody species, elder (Sambucus nigra L.) showed an increased frequency. Also invasive alien species increased, mainly Impatiens glandulifera Royle and Erechtites hieraciifolia (L.) Raf. ex DC.
When comparing groups of sites for the occurrence of selected nitrophilous species, there were no statistically significant differences in $\mathrm{N}$ concentration (Tab. 2), while the $\mathrm{C} / \mathrm{N}$ ratio, which provides a better evidence of ecosystem $\mathrm{N}$ saturation, differed among sites (Tab. 2).

\section{Changes in soil}

Soil pH increased (Fig. 2) between the two soil surveys, which means that forest soil was less acid in 2006 than in 1995. Con-

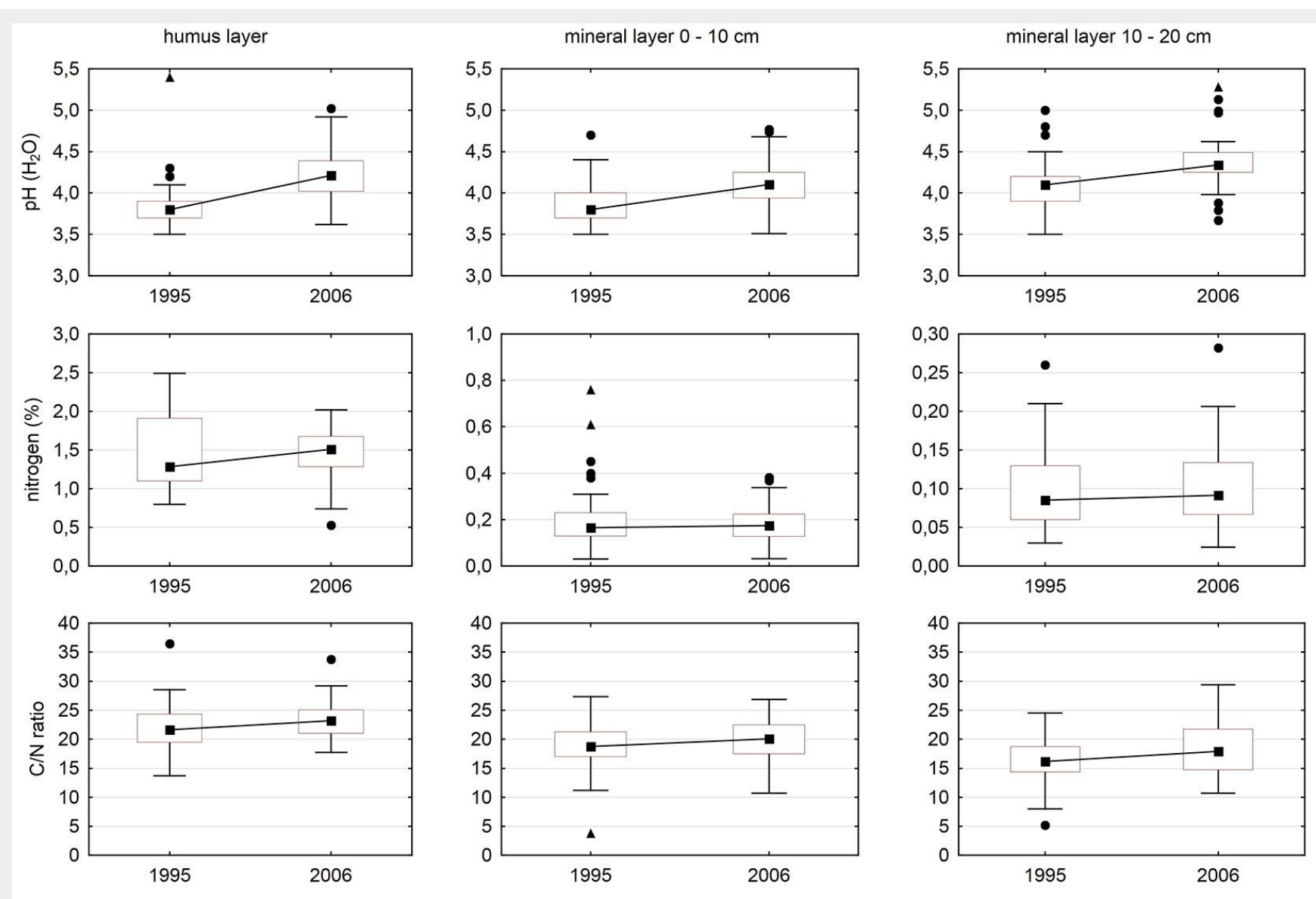

- median $\square 25 \%-75 \%$ quantiles Inon-outlier range • outliers ^ extreme values

Fig. 2 - Box plots for selected parameters according to soil layer and year of soil survey. 
Tab. 3 - Significance of differences in selected soil parameters between 1995 and 2006 after non-parametric pair tests. (ST): Sign test; (WPT): Wilcoxon pair test; (FH): humus layer; (M01): mineral soil (0-10 cm); (M12): mineral soil $(10-20 \mathrm{~cm})$.

\begin{tabular}{|c|c|c|c|c|}
\hline \multirow{2}{*}{ Parameter } & \multirow{2}{*}{ Horizon } & \multirow{2}{*}{$\mathrm{n}$} & \multicolumn{2}{|c|}{$p$-value } \\
\hline & & & ST & WPT \\
\hline \multirow[t]{3}{*}{$\mathrm{pH}\left(\mathrm{CaCl}_{2}\right)$} & $\mathrm{FH}$ & 65 & 0.000 & 0.000 \\
\hline & M01 & 66 & 0.010 & 0.003 \\
\hline & M12 & 64 & 0.004 & 0.000 \\
\hline \multirow[t]{3}{*}{$\mathrm{pH}\left(\mathrm{H}_{2} \mathrm{O}\right)$} & $\mathrm{FH}$ & 65 & 0.000 & 0.000 \\
\hline & M01 & 66 & 0.000 & 0.000 \\
\hline & M12 & 66 & 0.000 & 0.000 \\
\hline \multirow[t]{3}{*}{ carbon } & $\mathrm{FH}$ & 66 & 0.036 & 0.006 \\
\hline & M01 & 66 & 0.000 & 0.000 \\
\hline & M12 & 66 & 0.000 & 0.000 \\
\hline \multirow[t]{3}{*}{ nitrogen } & $\mathrm{FH}$ & 66 & 0.176 & 0.072 \\
\hline & M01 & 66 & 0.000 & 0.000 \\
\hline & M12 & 66 & 0.000 & 0.000 \\
\hline \multirow[t]{3}{*}{$\mathrm{C} / \mathrm{N}$ ratio } & $\mathrm{FH}$ & 66 & 0.110 & 0.047 \\
\hline & M01 & 66 & 0.005 & 0.060 \\
\hline & M12 & 66 & 0.110 & 0.015 \\
\hline
\end{tabular}

Tab. 4 - Significance of differences in total nitrogen deposition and total $\mathrm{H}^{+}$ions deposition between 1995, 2004 and 2006 after non-parametric pair tests. (ST): Sign test; (WPT): Wilcoxon pair test; $(\mathrm{N})$ : total nitrogen deposition; $(\mathrm{H}+)$ : total acid deposition.

\begin{tabular}{ccc}
\hline \multirow{2}{*}{ Pair Comparison } & \multicolumn{2}{c}{$p$-value } \\
\cline { 2 - 3 } & ST & WPT \\
\hline N 1995 - N 2004 & 0.000 & 0.000 \\
N 1995- N 2006 & 0.000 & 0.000 \\
N 2004- N 2006 & 0.065 & 0.121 \\
H+ 1995- H+ 2004 & 0.000 & 0.000 \\
H+ 1995- H+ 2006 & 0.000 & 0.000 \\
H+ 2004- H+ 2006 & 0.000 & 0.000 \\
\hline
\end{tabular}

centrations of carbon and $\mathrm{N}$ in soil increased as well. Increase in carbon was higher than increase in $\mathrm{N}$, thus resulting in an increased $\mathrm{C} / \mathrm{N}$ ratio.

Differences between the two surveys were significant in nearly all cases (Tab. 3).

The difference between total $\mathrm{N}$ deposition in 2004 and 2006 was non-significant (Tab. 4), while other differences were highly significant. Deposition was higher in 1995 than 10 years later (Fig. 3).

\section{Relationship between deposition load} and soil parameters

Correlations between deposition in 1995 and soil parameters in 1995 and between deposition in 2004 and in 2006 and soil parameters in 2006 were tested. The results are reported in Tab. 5 .

In 1995 total $\mathrm{N}$ deposition increased with decreasing $\mathrm{pH}$ in the humus layer and $0-10$ $\mathrm{cm}$ mineral soil, while $\mathrm{N}$ deposition and $\mathrm{N}$ concentration increased in tandem at depth $0-10 \mathrm{~cm}$ of mineral soil. In the mineral soil layer at $10-20 \mathrm{~cm}$, total $\mathrm{N}$ deposition and $\mathrm{N}$ concentration were significantly correlated. When the relationship between total $\mathrm{H}^{+}$ions deposition and soil parameters was tested, there was only a negative correlation with $\mathrm{pH}$ in the mineral soil. $\mathrm{A}$ stronger effect was visible at 0-10 cm mineral soil depth. No significant correlation was found between total $\mathrm{H}^{+}$ions deposition and $\mathrm{N}$ concentration as well as $\mathrm{C} / \mathrm{N}$ ratio, and between total $\mathrm{N}$ deposition and $\mathrm{C} / \mathrm{N}$ ratio.

In 2006, we tested the influence of total $\mathrm{N}$ deposition and total $\mathrm{H}^{+}$ions deposition

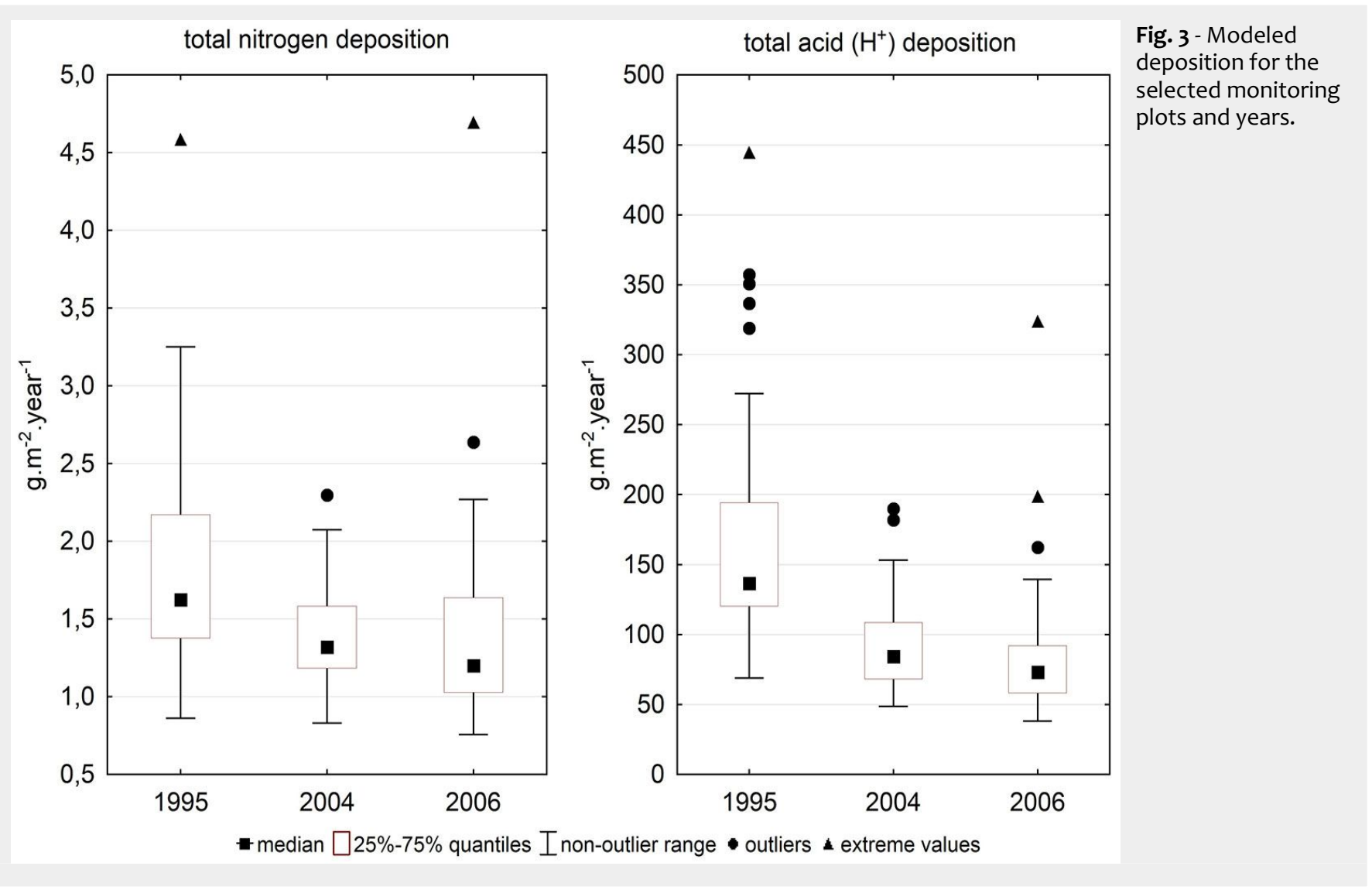


Tab. 5 - Correlation between total nitrogen deposition and total $\mathrm{H}^{+}$ions deposition and selected soil parameters. For each parameter/horizon combination, the $P$-values (first row, in italic) and the correlation coefficient (second row) are reported. (S-R): Spearman $\mathrm{R}$ correlation test; (K-T): Kendall Tau correlation test; (FH): humus layer; (M01): mineral soil (0-10 cm); (M12): mineral soil (10-20 cm).

\begin{tabular}{|c|c|c|c|c|c|c|c|c|c|c|c|c|c|}
\hline \multirow{3}{*}{$\begin{array}{l}\text { Parameter } \\
(1995 / 2006)\end{array}$} & \multirow{3}{*}{ Horizon } & \multicolumn{6}{|c|}{ Total nitrogen deposition } & \multicolumn{6}{|c|}{ Total acid deposition } \\
\hline & & \multicolumn{2}{|c|}{$\begin{array}{c}1995(n=66) \\
p \text {-value/ } \\
\text { corr. coef. }\end{array}$} & \multicolumn{2}{|c|}{$\begin{array}{c}2004(\mathrm{n}=66) \\
p \text {-value/ } \\
\text { corr. coef. }\end{array}$} & \multicolumn{2}{|c|}{$\begin{array}{c}2006(n=66) \\
p \text {-value/ } \\
\text { corr. coef. }\end{array}$} & \multicolumn{2}{|c|}{$\begin{array}{c}1995(n=65) \\
p \text {-value/ } \\
\text { corr. coef. }\end{array}$} & \multicolumn{2}{|c|}{$\begin{array}{c}2004(\mathrm{n}=66) \\
p \text {-value/ } \\
\text { corr. coef. }\end{array}$} & \multicolumn{2}{|c|}{$\begin{array}{c}2006(n=66) \\
p \text {-value/ } \\
\text { corr. coef. }\end{array}$} \\
\hline & & S-R & K-T & S-R & K-T & S-R & K-T & S-R & K-T & S-R & K-T & S-R & K-T \\
\hline \multirow[t]{5}{*}{$\mathrm{pH}\left(\mathrm{CaCl}_{2}\right)$} & $\mathrm{FH}$ & 0.040 & 0.030 & 0.613 & 0.484 & 0.294 & 0.296 & 0.258 & 0.238 & 0.868 & 0.841 & 0.113 & 0.107 \\
\hline & & -0.25 & -0.18 & -0.06 & -0.06 & 0.13 & 0.09 & -0.14 & -0.10 & 0.02 & 0.02 & 0.20 & 0.14 \\
\hline & M01 & $\begin{array}{c}0.019 \\
-0.29\end{array}$ & $\begin{array}{l}0.016 \\
-0.20\end{array}$ & $\begin{array}{l}0.835 \\
-0.03\end{array}$ & $\begin{array}{l}0.790 \\
-0.02\end{array}$ & $\begin{array}{l}0.527 \\
0.08\end{array}$ & 0.648 & 0.048 & 0.041 & $\begin{array}{l}0.721 \\
-0.04\end{array}$ & $\begin{array}{r}0.673 \\
-0.04\end{array}$ & $\begin{array}{l}0.496 \\
0.09\end{array}$ & $\begin{array}{l}0.483 \\
0.06\end{array}$ \\
\hline & M12 & 0.327 & 0.345 & 0.997 & 0.942 & 0.429 & 0.446 & 0.149 & 0.109 & 0.398 & 0.394 & 0.906 & 0.951 \\
\hline & & -0.12 & -0.08 & 0.00 & -0.01 & 0.10 & 0.06 & -0.18 & -0.14 & -0.11 & -0.07 & 0.01 & 0.01 \\
\hline \multirow[t]{6}{*}{$\mathrm{pH}\left(\mathrm{H}_{2} \mathrm{O}\right)$} & $\mathrm{FH}$ & 0.013 & 0.006 & 0.591 & 0.548 & 0.781 & $0 . .773$ & 0.109 & 0.113 & 0.971 & 0.991 & 0.615 & 0.594 \\
\hline & & -0.30 & -0.23 & -0.07 & -0.05 & 0.03 & 0.02 & -0.20 & -0.13 & 0.00 & 0.00 & 0.06 & 0.04 \\
\hline & M01 & 0.010 & 0.007 & 0.619 & 0.541 & 0.592 & 0.640 & 0.059 & 0.041 & 0.640 & 0.697 & 0.590 & 0.593 \\
\hline & & -0.32 & -0.23 & -0.06 & -0.05 & 0.07 & 0.04 & -0.24 & -0.17 & -0.06 & -0.03 & 0.07 & 0.04 \\
\hline & M12 & 0.126 & 0.102 & 0.429 & 0.396 & 0.769 & 0.780 & 0.125 & 0.093 & 0.189 & 0.215 & 0.706 & 0.754 \\
\hline & & -0.19 & -0.14 & -0.10 & -0.07 & 0.04 & 0.02 & -0.19 & -0.14 & -0.16 & -0.10 & -0.05 & -0.03 \\
\hline \multirow[t]{6}{*}{ Nitrogen } & $\mathrm{FH}$ & 0.350 & 0.392 & 0.048 & 0.042 & 0.562 & 0.532 & 0.265 & 0.258 & 0.770 & 0.778 & 0.356 & 0.301 \\
\hline & & -0.12 & -0.07 & 0.24 & 0.17 & 0.07 & 0.05 & -0.14 & -0.10 & 0.04 & 0.02 & -0.12 & -0.09 \\
\hline & M01 & 0.004 & 0.005 & 0.060 & 0.058 & 0.141 & 0.149 & 0.311 & 0.345 & 0.999 & 0.960 & 0.681 & 0.761 \\
\hline & & 0.35 & 0.24 & 0.23 & 0.16 & 0.18 & 0.12 & 0.13 & 0.08 & 0.00 & 0.00 & -0.05 & -0.03 \\
\hline & M12 & 0.076 & 0.056 & 0.031 & 0.040 & 0.098 & 0.069 & 0.377 & 0.369 & 0.961 & 0.881 & 0.883 & 0.969 \\
\hline & & 0.22 & 0.16 & 0.27 & 0.17 & 0.21 & 0.15 & 0.11 & 0.08 & 0.01 & 0.01 & -0.02 & 0.00 \\
\hline \multirow[t]{6}{*}{$\mathrm{C} / \mathrm{N}$ ratio } & $\mathrm{FH}$ & 0.309 & 0.367 & 0.000 & 0.000 & 0.000 & 0.000 & 0.993 & 0.955 & 0.002 & 0.002 & 0.072 & 0.074 \\
\hline & & 0.13 & 0.08 & -0.50 & -0.35 & -0.44 & -0.32 & 0.00 & 0.00 & -0.38 & -0.26 & -0.22 & -0.15 \\
\hline & M01 & 0.676 & 0.634 & 0.035 & 0.053 & 0.055 & 0.055 & 0.362 & 0.300 & 0.023 & 0.022 & 0.144 & 0.146 \\
\hline & & 0.05 & 0.04 & -0.26 & -0.16 & -0.24 & $-0 . .16$ & 0.11 & 0.09 & -0.28 & -0.19 & -0.18 & -0.12 \\
\hline & M12 & 0.809 & 0.710 & 0.593 & 0.559 & 0.225 & 0.197 & 0.578 & 0.610 & 0.373 & 0.367 & 0.344 & 0.350 \\
\hline & & 0.03 & 0.03 & -0.07 & -0.04 & -0.15 & -0.11 & 0.07 & 0.04 & -0.11 & -0.08 & -0.12 & -0.08 \\
\hline
\end{tabular}

on soil chemistry for the same year of the soil survey (in 2006) and we also tested the influence of deposition calculated in 2004 and its correlation with soil chemistry in 2006. We found more significant results for deposition data in 2004 and soil data in 2006 than for deposition data in 2006 and soil data in 2006. Total $\mathrm{N}$ deposition in 2004 increased with increasing $\mathrm{N}$ concentration in the humus layer and in the mineral soil at $10-20 \mathrm{~cm}$ depth in 2006 . Total $\mathrm{N}$ deposition in 2004 decreased with increasing $\mathrm{C} / \mathrm{N}$ ratio in the humus layer and $\mathrm{min}$ eral top soil at 0-10 cm in 2006. Correlation between total $\mathrm{N}$ deposition in 2006 and selected soil parameters in 2006 was significant only for $\mathrm{C} / \mathrm{N}$ ratio in the humus layer. Total $\mathrm{H}^{+}$ions deposition in 2004 was negatively correlated with $\mathrm{C} / \mathrm{N}$ ratio in the humus layer and mineral top soil at $0-10 \mathrm{~cm}$ in 2006. Total $\mathrm{H}^{+}$ions deposition in 2006 was significant only for $\mathrm{C} / \mathrm{N}$ ratio in the humus layer in 2006.

\section{Discussion}

During the past 20 years, a higher proportion of nitrophilous species was detected in Czech forests (Buriánek et al. 2013), likely due to the elevated $\mathrm{N}$ deposition. Similar results have been reported across Europe (Gilliam 2006, Fischer et al. 2012). The gradual replacement of oligotrophic species by eutrophic species as a response to $\mathrm{N}$ deposition has been observed at the European scale based on long-term monitoring at 28 forest sites with a total of 1335 permanent forest floor vegetation plots (Dirnböck et al. 2014). The spread of nitrophilous species throughout the forest suggests the $\mathrm{N}$ saturation of forest ecosystems. While the overall $\mathrm{N}$ deposition slightly decreased, in some regions there was again a weak increase (Hůnová et al. 2014). A slight but significant increase of nitrophilous species within the ICP Forests monitoring plots in Europe in connection with $\mathrm{N}$ deposition is reported also by Seidling et al. (2008).

Changes in total $\mathrm{N}$ concentration in forest soil between the surveys in 1995 and in 2006 and correlation between total $\mathrm{N}$ deposition and total $\mathrm{N}$ concentration in soil were significant. The relationship between 2004 deposition and 2006 soil chemistry was more significant than the relationship between deposition load and soil chemistry in the same year. This confirms that there is a time lag between the input of the compounds to the forest and their measurable effects on the ecosystem. Results from $\mathrm{N}$ deposition measurements across Europe confirm our findings - there is a slight decrease in $\mathrm{N}$ deposition, but critical deposition loads for nutrient $\mathrm{N}$ are exceeded in more than half of the monitoring plots in Europe (Seidling et al. 2014). Critical loads for inorganic $\mathrm{N}$ deposition were exceeded on about a third to a half of the monitored forest plots of the ICP Forests Level II network across Europe (Waldner et al. 2015). Elevated inorganic $N$ concentrations in soil solution occurred more frequently in these plots (Waldner et al. 2015). Indications of nutrient imbalances, such as low magnesium concentration in foliage or discoloration of needles and leaves, were rare but appeared more frequently on plots where the critical limits for soil solution were exceeded (Waldner et al. 2015). Also in the Czech Republic there are regions where elevated $\mathrm{N}$ concentration in soil leads to nutrient imbalance, especially between $\mathrm{N}$ and phosphorus and $\mathrm{N}$ and magnesium (Lomský et al. 2011, 2012).

Our results show that all evaluated soil horizons (humus layer and mineral soil up to $20 \mathrm{~cm}$ depth) are affected by high $\mathrm{N}$ input. This is an important confirmation that not only the soil surface is influenced. It clearly shows that forest soil is already saturated by $\mathrm{N}$ in some regions and that there is mid- or long-term influence of $\mathrm{N}$ compounds on forest soil. If the soil is $\mathrm{N}$ saturated, there is a risk of high leaching of $\mathrm{N}$ compounds to the ground water. In the Czech Republic, the monitoring of runoff water in small forest catchments confirms this finding, as the concentration of nitrate is quite high $\left(>5 \mathrm{mg} \mathrm{l}^{-1}\right)$ and related with high $\mathrm{N}$ deposition (Vícha et al. 2012).

Moreover, the realistic nitrogen deposition in Czech forests is likely to be much higher than the modeled values used for our analysis. The $\mathrm{N}$ deposition is likely to be substantially underestimated not accounting for several important non-measured compounds, such as $\mathrm{NH}_{3}$ and $\mathrm{HNO}_{3}$ (g), and contribution of occult deposition, as recently shown by Hůnová et al. (2016).

\section{Conclusions}

There is a significant influence of $\mathrm{N}$ depo- 
sition on forest soil in the Czech Republic; between 1995 and 2006, concentration of total $\mathrm{N}$ increased in the upper $20 \mathrm{~cm}$ of soil. Deposition load exceeded the critical threshold for forest ecosystem in the Czech Republic. The results suggest that $\mathrm{N}$ deposition still represents a threat for forest ecosystems in the Czech Republic.

\section{Acknowledgements}

For their support we would like to thank the Ministry of Agriculture of the Czech Republic, Projects No. RO0114 (č.j. 8653/ 2014-MZE-17011) and No. QI112A168 ("Forest soil as the determining factor for forest health, biodiversity and the base for forest production, as well as for nonproductive functions"). We also highly appreciate the comments of three anonymous reviewers who substantially enhanced our manuscript. Last but not least we thank Sharon King for proofreading the paper.

\section{References}

Augustin S, Bolte A, Holzhausen M, Wolff B (2005). Exceedance of critical loads of nitrogen and sulphur and its relation to forest conditions. European Journal of Forest Research 124 (4): 289-300. - doi: 10.1007/s10342-005-0095-1

Braun-Blanquet J (1965). Plant sociology, the study of plants communities. Hafner, London, UK, pp. 439.

Braun S, Thomas VFD, Quiring R, Flückiger W (2010). Does nitrogen deposition increase forest production? The role of phosphorus. Environmental Pollution 158 (6): 2043-2052. - doi: 10.1016/j.envpol.2009.11.030

Buriánek V, Novotný R, Hellebrandová K, Šrámek $V$ (2013). Ground vegetation as an important factor in the biodiversity of forest ecosystems and its evaluation in regard to nitrogen deposition. Journal of Forest Science 59 (3): 238-252. [online] URL: http://www.agriculturejournals.cz /publicFiles/96315.pdf

Canullo R, Starlinger F, Granke $\mathrm{O}$, Fischer R, Aamlid D, Neville P (2011). Assessment of ground vegetation. Manual Part VII: 18. In: "Manual on methods and criteria for harmonized sampling, assessment, monitoring and analysis of the effects of air pollution on forests". UNECE, ICP Forests Programme Coordinating Centre, Hamburg, Germany, pp. 1-15. Corre MD, Brumme R, Veldkamp E, Beese FO (2007). Changes in nitrogen cycling and retention processes in soils under spruce forests along a nitrogen enrichment gradient in Germany. Global Change Biology 13 (7): 1509-1527. doi: $10.1111 / j .1365-2486.2007 .01371 . x$

De Vries W, Dobbertin MH, Solberg S, Van Dobben HF, Schaub M (2014). Impacts of acid deposition, ozone, exposure and weather conditions on forest ecosystems in Europe: an overview. Plant and Soil 380: 1-45. - doi: 10.1007/s11104-014-2056-2

De Vries W, Reinds GJ, Van Kerkvoorde MS, Hendriks CMA, Leeters EEJM, Gross CP, Voogd JCH, Vel EM (2000). Intensive monitoring of forest ecosystems in Europe: 2000 technical report. EC, UN/ECE 2000, Brussels, Belgium and Geneva, Switzerland, pp. 191.

Dirnböck T, Grandin U, Bernhardt-Römermann
M, Beudert B, Canullo R, Fosius M, Grabner MT, Holmberg $M$, Kleemola S, Lundin L, Mirtl M, Neumann M, Pompei E, Salemaa M, Starlinger F, Staszewki T, Uzibo KA (2014). Forest floor vegetation response to nitrogen deposition in Europe. Global Change Biology 20 (2): 429-440. - doi: 10.1111/gcb.12440

Fabiánek P (2004). Monitoring stavu lesa v České republice 1984-2003 [Forest condition monitoring in the Czech Republic 1984-2003]. Ministry of Agriculture of the Czech Republic, Forestry and Game Management Research Institute, Prague, Czech Republic, pp. 431. [in czech]

Fischer R, Waldner P, Carnicer J, Coll M, Dobbertin $M$, Ferretti $M$, Hansen $K$, Kindermann $G$, Lasch-Born P, Lorenz M, Marchetto A, Meining $\mathrm{S}$, Nieminen T, Penuelas J, Rautio P, Reyer C, Roskams P, Sánchez G (2012). The condition of forests in Europe: 2012 executive report. ICP Forests, Hamburg, Germany, pp. 24. [online] URL: http://www.icp-forests.org/RepEx.htm

Fujita Y, De Ruiter PC, Wassen MJ, Heil GW (2010). Time dependent, species-specific effects of N: P stoichiometry on grassland plant growth. Plant and Soil 334: 99-112. - doi: 10.1007/s11104-010-0495-y

Gilliam FS (2006). Response of the herbaceous layer of forest ecosystems to excess nitrogen deposition. Journal of Ecology 94 (6): 1176-1191. - doi: 10.1111/j.1365-2745.2006.01155.x

Hůnová I, Kurfürst $P$, Maznová J, Coňková M (2011). The contribution of occult precipitation to sulphur deposition in the Czech Republic. Erdkunde Archive for Scientific Geography 65: 247-259. - doi: 10.3112/erdkunde.2011.03.03

Hůnová I, Maznová J, Kurfürst P (2014). Trends in atmospheric deposition fluxes of sulphur and nitrogen in Czech forest. Environmental Pollution 184: 668-675. - doi: 10.1016/j.envpol.2013. 05.013

Hůnová I, Kurfürst $P$, Vlček O, Stráník V, Stoklasová P, Schovánková J, Srbová D (2016). Towards a better spatial quantification of nitrogen deposition: a case study for Czech forests. Environmental Pollution 213: 1028-1041. - doi: 10.1016/j.envpol.2016.01.061

Jandl R, Smidt S, Mutsch F, Fürst A, Zechmeister H, Bauer H, Dirnböck T (2012). Acidification and nitrogen eutrophication of Austrian forest soils. Applied and Environmental Soil Science 2012 (3): 1-9. - doi: 10.1155/2012/632602

Johnston K, Ver Hoef J, Krivoruchko K, Lucas N (2001). Using ArcGIS Geostatistical Analyst. Environmental Systems Research Institute, Redlands, CA, USA, pp. 300. [online] URL: http://www.researchgate.net/publication/2000 43204

Katzensteiner K, Galtzel G, Kazda M (1992). Nitrogen-induced nutritional imbalances - a contributing factor to Norway spruce decline in the Bohemian Forest (Austria). Forest Ecology and Management 51 (1-3): 29-42. - doi: 10.1016/03781127(92)90469-P

Kreutzer K, Butterbach-Bahl K, Rennenberg $\mathrm{H}$, Papen $H$ (2009). The complete nitrogen cycle of an N-saturated spruce forest ecosystem. Plant Biology 11 (5): 643-649. - doi: 10.1111/j.14388677.2009.00236.x

Lochman V, Maxa M, Bíba M (2006). Development of soil chemistry on FGMRI research plots during reduction of air pollution fallout. Zprávy lesnického výzkumu 51 (2): 106-120.

Lomský B, Materna J, Pfanz H (2002). SO 2 -pollution and forests decline in the Ore Mountains. Forestry and Game Management Research Institute, Strnady, Czech Republic, pp. 342.

Lomský B, Šrámek V (2004). Different types of damage in mountain forest stands of the Czech Republic. Journal of Forest Science 50: 533-537. [online] URL: http://agriculturejournals.cz/pub licFiles/55402.pdf

Lomský B, Novotný R, Šrámek V (2011). Změny ve výživě fosforem $v$ mladých smrkových porostech. [Changes in phosphorus supply in the young stands of Norway spruce]. Zprávy lesnického výzkumu [Reports of forestry research] 56 (2): 83-93. [in Czech]

Lomský B, Šrámek V, Novotný R (2012). Changes in the air pollution load in the Jizera Mts.: effects on the health status and mineral nutrition of the young Norway spruce stands. European Journal of Forest Research 131: 757-771. doi: 10.1007/s10342-011-0549-6

Materna J (1986). The influence of pollution on the mineral nutrition of tree species. Lesnictví 32: 569-580.

Mellert KH, Gensior A, Kölling C (2005). Nitrogen saturation in Bavarian forests - results of the nitrate inventory. Forstarchiv 76 (2): 35-43.

Mellert KH, Prietzel J, Straussberger R, Rehfuess KE, Kahle HP, Perez P, Spiecker H (2008). Relationships between long-term trends of air temperature, precipitation, nitrogen nutrition and growth of coniferous stands in Central Europe and Finland. European Journal of Forest Research 127: 507-524. - doi: 10.1007/s10342-0080233-7

Okland RH (1995). Changes in the occurrence and abundance of plant species in a Norwegian boreal coniferous forests, 1988-1993. Nordic Journal of Botany 15 (4): 415-438. - doi: 10.1111/ j.1756-1051.1995.tboo174.x

Podrázský V, Remeš J (2007). Changes of soil chemistry in the Norway spruce forest ecosystems of the middle altitudes. Scientia Agriculturae Bohemica 38 (1): 48-51. [online] URL: http://agris.fao.org/agris-search/search.do?reco rdID $=C Z 2007000321$

Posch M, Slootweg J, Hettelingh JP (2012). Modelling and mapping of atmospherically-induced ecosystem impacts in Europe. CCE Status Report 2012, Coordination Centre for Effects, RIVM, Bilthoven, The Netherlands, pp. 141.

Rampazzo N, Blum WEH (1992). Changes in chemistry and mineralogy of forest soils by acid rain. Water, Air and Soil Pollution 61 (3-4): 209220. - doi: 10.1007/BF00482605

Reich PB, Knops J, Tilman D, Craine J, Ellsworth D, Tjoelker M, Lee T, Wedin D, Naeem S, Bahauddin D, Hendrey Jose G S, Wrage K, Goth J, Bengston W (2001). Plant diversity enhances ecosystem responses to elevated $\mathrm{CO}_{2}$ and nitrogen deposition. Nature 410: 809-812. - doi: $10.1038 / 35071062$

Rothe A, Huber C, Kreutzer K, Weis W (2002). Deposition and soil leaching in stands of Norway spruce and European beech: results from the Höglwald research in comparison with other European case studies. Plant and Soil 240 (1): 33-45. - doi: 10.1023/A:1015846906956 Salih N, Andersson F (1999). Nutritional status a 
Norway spruce stand in SW Sweden in response to compensatory fertilization. Plant and Soil 209: 85-100. - doi: 10.1023/A:1004528 102242

Schaaf W, Wecker B, Pan T, Hüttl RH (2004). Changes in top soil properties of forest soils in north-eastern Germany due to long-term element accumulation. Plant and Soil 264: 85-95. doi: 10.1023/B:PLSO.0000047713.27594.70

Seidling W, Fischer R, Granke O (2008). Relationship between forest floor vegetation on ICP Forests monitoring plots in Europe and basic variables in soil and nitrogen deposition. International Journal of Environmental Studies 65 (3): 311-322. - doi: 10.1080/00207230701862538 Seidling W, Sanders T, Akselsson C, Cools N, De Marco A, De Vos B, De Vries W, Etzold S, Ferretti $M$, Fischer $U$, Giordani $P$, Graf Pannatier $E$, Hansen K, Jonard M, Marchetto A, Nevenic R, Rautio P, Reinds G, Skudnik M, Solberg S, Suz LM, Ukonmaanaho L, Vanguelova E, Veresoglou S, Waldner P, Wattel-Koekkoek E, Fischer $R$ (2014). The condition of forests in Europe: 2013 executive report. ICP Forests, Eberswalde, pp. 36. [online] URL: http://www.icp-forests. org/RepEx.htm

Schulze ED, Beck E, Müller-Hohenstein K (2005). Plant ecology. Springer Verlag, Berlin, Heidelberg, Germany, pp. 702.

Singer J (1916). Über Rauhreif und Duftbruch im Erzgebirge [About rime and rimebreak in Ore Mts.]. Centralblatt fürdas gesamteForstwesen 5/6: 161. [in German]

Solberg S, Andreassen K, Clarke N, Torseth K, Tveito OE, Strand GH, Tomter S (2004). The possible influence of nitrogen and acid deposition on forest growth in Norway. Forest Ecology and Management 192 (2-3): 241-249. - doi: 10.1016/j.foreco.2004.01.036
Solberg S, Dobbertin M, Reinds GJ, Lange $H$, Andreassen K, Fernandez PG, Hildingsson A, De Vries W (2009). Analyses of the impact of changes in atmospheric deposition and climate on forest growth in European monitoring plots: a stand growth approach. Forest Ecology and Management 258 (8): 1735-1750. - doi: 10.1016/ j.foreco.2008.09.057

Stoklasa J (1923). Bechädigung de Vegetation durch Rauchgase und Fabriksexhalationen. [Damage to the vegetation by fumes and factory exhalations] Urban und Schwarzwenberg Verlag, Wien, Austria and Berlin, Germany, pp. 487. [in German]

UNECE (2006). Part IIla - Sampling and analysis of soil. In: "Manual on methods and criteria for harmonized sampling, assessment, monitoring and analysis of the effects of air pollution on forests". UNECE, ICP Forests, Hamburg, Germany. [online] URL: http://www.icp-forests.org /Manual.htm

Vícha Z, Lochman V, Bíba M (2012). Depozice dusíku v lesních porostech a jejich vliv na obsah nitrátu v odtékající vodě a na okyselování pudy. [Nitrogen deposition in the forest stands and the effect on nitrate amount in runoff water and on soil acidification]. Zprávy lesnického výzkumu 57 (4): 352-360. [in Czech]

Waldner P, Thimonier A, Pannatier EG, Etzold S, Schmitt M, Marchetto A, Rautio P, Derome K, NieminenTM, Nevalainen $S$, Lindroos A, Merilä P, Kindermann G, Neumann M, Cools N, De Vos B, Roskams P, Verstraeten A, Hansen K, Karlsson GP, Dietrich HP, Raspe S, Fischer R, Lorenz M, lost S, Granke O, Sanders TGM, Michel A, Nagel HD, Scheuschner T, Simoncic P, Von Wilpert K, Meesenburg H, Fleck S, Benham S, Vanguelova $\mathrm{E}$, Clarke N, Ingerslev $\mathrm{M}$, Vesterdal L, Gundersen P, Stupak I, Jonard M, Potocic N,
Minaya M (2015). Exceedance of critical loads and of critical limits impacts tree nutrition across Europe. Annals of Forest Science 72 (7): 929-939. - doi: 10.1007/s13595-015-0489-2 Wamelink GWW, Van Dobben HF, Mol-Dijkstra JP, Schouwenberg EPAG, Kros J, De Vries W, Berendse F (2008). Effect of nitrogen deposition reduction on biodiversity and carbon sequestration. Forest Ecology and Management 258 (8): 1774-1779. - doi: 10.1016/j.foreco.2008. 10.024

Wesselink LG, Meiwes KJ, Matzner E, Stein A (1995). Long-term changes in water and soil chemistry in spruce and beech forests, Solling, Germany. Environmental Science and Technology 29 (1): 51-58. - doi: 10.1021/esooo01aoo6

Zapletal M (1998). Atmospheric deposition of nitrogen compounds in the Czech Republic. Environmental Pollution 29 (102): 305-311. - doi: 10.1016/S0269-7491(98)80048-1

Zapletal M (2001). Atmospheric deposition of nitrogen and sulphur compounds in the Czech Republic. The Scientific World 1 (S2): 294-303. [online] URL: http://www.hindawi.com/journals /tswj/2001/121357/abs/

Zapletal M (2006). Atmospheric deposition of nitrogen and sulphur in relation to critical loads of nitrogen and acidity in the Czech Republic. Journal of Forest Science 52: 92-100. [online] URL: http://agriculturejournals.cz/publicFiles/55 080.pdf

Zapletal M (2014). Historický vývoj atmosférické depozice síry a dusíku v České republice [Historical development of atmospheric deposition of sulphur and nitrogen in the Czech Republic]. Silesian University in Opava, Faculty of Philosophy and Science, Institute of Historical Sciences, Opava, Czech Republic, pp. 136. [in Czech] 